\title{
EWOLUCJA SYSTEMU KONTROLI WEWNĘTRZNEJ W JEDNOSTKACH SAMORZĄDU TERYTORIALNEGO NA PRZESTRZENI 25 LAT SAMORZĄDNOŚCI W POLSCE
}

\section{WSTĘP}

Rok 2015 jest rokiem jubileuszowym z dwóch powodów. Po pierwsze w Polsce obchodzimy 25-lecie istnienia samorządności, a po drugie mija 5 lat od wdrożenia kontroli zarządczej w sektorze publicznym. Jest to dobry moment, aby podsumować ten okres w odniesieniu do kontroli wewnętrznej w samorządach, począwszy od $1990 \mathrm{r}$.

Kontrola wewnętrzna na przestrzeni minionych lat znacznie ewoluowała. Zmieniało się podejście do systemu, poszczególne organy samorządu otrzymywały nowe uprawnienia kontrolne, a także po dziś dzień trwa proces udoskonalania i przegląd procedur, zwłaszcza od strony efektywności i skuteczności.

W pierwszej części publikacji omówiono istotę oraz rolę kontroli wewnętrznej w administracji publicznej. Dokonano analizy kontroli wewnętrznej jako systemu, czy też procesu, na który składa się wiele czynników i elementów. Przytoczono model kontroli wewnętrznej według Committe of Sponsoring Organizations of the Treadway Commision (COSO, Komisja). W drugiej i trzeciej części przedstawiono funkcjonowanie kontroli wewnętrznej w samorządach od 1990 r. po dziś dzień. Autor zaproponował model ewolucji tego systemu, który odnosi się do pierwotnych, aktualnych i ewentualnych przyszłych praktyk związanych z kontrolą wewnętrzną oraz jej elementów. Przedstawiono również wyniki ankiety przeprowadzonej w samorządach, dotyczącej zagadnień z zakresu kontroli zarządczej i audytu wewnętrznego.

Celem niniejszego opracowania jest podsumowanie funkcjonowania systemu kontroli wewnętrznej. Ponadto zasadne będzie wskazanie najważniejszych spraw związanych z kontrolą wewnętrzną i zarządcza, tak aby stanowiła ona wartość dodaną zarządzania jednostką samorządu terytorialnego (jst). Zdaniem autora kontrola zarządcza nie może być postrzegana wyłącznie jako porównywanie stanu oczekiwanego z faktycznym. Ze względu chociażby już na samą nazwę powinna odnosić się do procesu zarządzania z nastawieniem na efektywność i skuteczność realizowanych zadań. Rozważania te podjęto również w niniejszej pracy z uwagi na zbytnie zawężanie znaczenia kontroli zarządczej oraz niedocenianie jej przez pracowników samorządowych. 


\section{KONTROLA WEWNĘTRZNA W ADMINISTRACJI PUBLICZNEJ - ISTOTA ORAZ ROLA}

Zagadnienie definicji kontroli oraz jej klasyfikacji było wielokrotnie poruszane w literaturze. W związu z tym przedmiotem niniejszej części artykułu nie będzie gruntowna analiza pojęć związanych z procesem kontroli. Zasadne jednak wydaje się przypomnienie najważniejszych kwestii związanych z tym zagadnieniem, co pozwoli określić rolę i miejsce kontroli w administracji publicznej, a zwłaszcza samorządowej. Oczywistą sprawa jest fakt, że kontrola odnosi się do porównywania stanu faktycznego z wymaganym przepisami prawa. Ponadto można stwierdzić, że jest ona częścią systemu zarządzania przez udzielanie zapewnienia o prawidłowości procesów zachodzących w jednostce.

$\mathrm{Na}$ wstępie warto zwrócić jeszcze uwagę na pojęcie nadzoru, który jest bardzo często błędnie utożsamiany z kontrolą. Istotna różnica dotyczy odpowiedzialności organu nadzorującego i kontrolującego. Znacznie większa odpowiedzialność spoczywa na organie nadzorującym. Odpowiada on za przebieg i osiagane wyniki nadzorowanej działalności ${ }^{1}$. Kontrola natomiast, nie odnosi się do sposobów i metod wyeliminowania stwierdzonych nieprawidłowości.

Dysponowanie środkami publicznymi przez samorządy oraz liczba zadań na nie nakładanych powoduja, że nieracjonalne byłoby ich funkcjonowanie bez skutecznego systemu kontroli. Najczęściej wyróżnić można dwa zasadnicze typy kontroli: kontrolę o charakterze zewnętrznym i wewnętrznym. Ze względu na to, że przedmiotem artykułu nie jest kontrola zewnętrzna, nie zostana podjęte rozważania $\mathrm{w}$ tym zakresie. Nadmienić jedynie należy, że organów kontroli zewnętrznej w odniesieniu do działalności samorządów jest wiele. Wśród tych instytucji można wymienić m.in. Najwyższą Izbę Kontroli, regionalne izby obrachunkowe, urzędy wojewódzkie, Państwową Inspekcję Pracy, Urząd Zamówień Publicznych, organy Komisji Europejskiej, a nawet w sprawach dotyczących popełnienia przestępstwa - prokuraturę, Centralne Biuro Antykorupcyjne i wiele innych.

Wdrażanie doktryny New Public Managment w samorządowej administracji publicznej przez wprowadzenie do polskiego porządku prawnego instrumentów audytu wewnętrznego, kontroli zarządczej jest wyrazem dokonywania zmian w zarządzaniu tymi instytucjami. Kolejnym krokiem ze strony ustawodawcy w reformie administracji samorządowej jest wieloletnie prognozowanie, które znajduje odzwierciedlenie w wieloletnich prognozach finansowych. Podjęte przez niektóre samorządy próby wdrażania budżetu zadaniowego wskazują na potrzebę modyfikacji na płaszczyźnie szeroko pojętego zarządzania, a nie tylko zarządzania finansowego.

W literaturze wiele miejsca poświęcono również definicji kontroli wewnętrznej. W niniejszym opracowaniu autor ograniczy się więc do przytoczenia tylko jednej. Według normy INTOSAI GOV 9100 kontrola wewnętrzna to integralny proces, na który wpływ ma kierownictwo jednostki oraz pracownicy. Proces ten zwraca uwagę na różne postacie ryzyka i dostarcza racjonalnego zapewnienia, że w działalności podmiotu realizującego swoją misję osiagnięte

${ }^{1}$ L. Kurowski, E. Ruśkowski, H. Sochacka-Krysiak, Kontrola finansowa w sektorze publicznym, Warszawa 2000, s. 22. 
zostaną cele ogólne. Ponadto jest to proces dynamiczny, który nieprzerwanie dostosowuje się do zmian, przed którymi staje jednostka².

Na podstawie wyżej przytoczonych definicji można stwierdzić, że kontrola wewnętrzna odnosi się do ogółu czynności i procedur składających się na proces zarządzania jednostka, a tę należy utożsamiać z pojęciem instytucji lub organizacji w znaczeniu rzeczowym. W tym miejscu wypada zauważyć, że na przestrzeni lat sama istota kontroli nie uległa zmianie. Natomiast ewoluował m.in. sposób jej przeprowadzenia w samorządzie, a także cele, jakim owa kontrola ma służyć. W działalności jednostek sektora publicznych została wyodrębniona kontrola zarządcza, która wyróżnia się tym, że jest sprawowana w ramach bieżącej działalności jst. Głównymi celami, jakie samorząd dzięki temu rodzajowi kontroli powinien osiagnaćc, są zwłaszcza efektywność i skuteczność jego funkcjonowania oraz realizacji zadań publicznych. Skuteczność tej kontroli będzie przejawiała się w dojrzałości danej jednostki do samokontroli oraz zmianach w systemie zarządzania. Można stwierdzić, że im lepszy model zarządzania (tzn. posiadający skuteczne mechanizmy kontroli oraz zapobiegania zjawiskom niepożądanym i obejmujaccy jak największy obszar funkcjonowania organizacji), tym większa zdolność tej instytucji do samokontroli. Zdaniem autora kontrola wewnętrzna jest systemem obejmującym wewnętrzne procedury, regulaminy oraz dobre praktyki, które mają służyć wypełnieniu misji jednostki i osiagnięcia założonych celów. Reasumując, wyróżnikiem kontroli zarządczej będzie sposób jej realizacji oraz cele, które należy postrzegać przez pryzmat zarządzania instytucją w kontekście skuteczności, efektywności i poprawy jakości realizowanych zadań publicznych.

Każda organizacja bez względu na to, czy jest to przedsiębiorstwo rynkowe, czy też administracja publiczna, potrzebuje dobrego systemu kontroli wewnętrznej. Samokontrola powinna spełniać zasadniczą rolę w realizacji celów i misji organizacji. Oczywiście podkreślenia wymaga fakt, że w jednostkach państwowych, w których obowiąuje budżet w układzie zadaniowym, oraz niektórych samorządach, które zdecydowały się na jego wprowadzenie, zdolność do samokontroli jest stosunkowo wysoka. Jednostki te mają bardziej klarownie sformułowane cele i zadania, a także mierniki ich realizacji. To powoduje, że bardzo istotna jest rola kontroli wewnętrznej w jak najbardziej efektywnym osiaganiu zaplanowanych zadań. Natomiast w jst, w których do tej pory nie zdecydowano się na dodatkowe opracowywanie budżetu w układzie zadaniowym, a do tego nie określono w sposób konkretny i jasny w odrębnych dokumentach ani misji, ani celów, ani też zadań - samo wdrożenie kontroli zarządczej jest procesem dość mozolnym, a często nawet niedocenianym, czy uważanym za zbędny. Zdaniem autora pomiędzy kontrolą zarządczą a planowaniem strategicznym znajduje się luka, która może zostać wypełniona z jednej strony przez wdrożenie budżetu zadaniowego, a z drugiej - przez zmianę mentalności i świadomości w realizacji zadań zarówno kadry zarządzającej, jak i pracowniczej.

W raporcie zatytułowanym Internal Control - Intergrated Framework (Kontrola wewnętrzna - zintegrowana struktura ramowa) zwrócono uwagę, że pojawiające się różnice nie tylko w rozumieniu pojęcia kontroli wewnętrznej,

${ }^{2}$ INTOSAI GOV 9100, Wytyczne w sprawie standardów kontroli wewnętrznej w sektorze publicznym, Najwyższa Izba Kontroli, Warszawa 2011, s. 9. 
ale również przebiegu całego procesu z nią związanego powodowały poważne trudności w zapewnieniu prawidłowego jej funkcjonowania. Komisja zakłada dynamiczny model wskazujący na zależności i wpływ na siebie poszczególnych elementów kontroli wewnętrznej. Proces ten ma za zadanie chronić jednostkę przed ujemnymi skutkami kontroli zewnętrznych.

Istotnym elementem kierowania jednostka jest zarządzanie ryzykiem. Kluczową częścią tego procesu jest ustanowienie celów. W swoim raporcie COSO zwraca uwagę, że ustalenie celów nie jest elementem kontroli wewnętrznej, niemniej stanowi warunek jej istnienia. W przeprowadzonej na potrzeby artykułu ankiecie w losowo wybranych jst wskazywano, że cele i zadania tych jednostek zostały określone w ustawach ustrojowych, w związku z czym zdaniem części ankietowanych nie zachodzi potrzeba ustalania celów w odrębnym dokumencie. Jednak wymagania w stosunku do dzisiejszej administracji znacznie się zmieniły na przestrzeni 25 lat funkcjonowania samorządu terytorialnego. Głównym czynnikiem oceny samorządu jest jego skuteczność w realizowaniu zadań, a więc zasadne jest określenie misji i celów. Ułatwi to ustalenie wskaźników służących pomiarowi efektywności realizowanych zadań. Ponadto w odczuciu lokalnej społeczności oraz instytucji zewnętrznych jst będzie postrzegana jako profesjonalny partner biznesowy, co może przełożyć się na jej rozwój społeczno-gospodarczy. Na ten czynnik znaczny nacisk stawia właśnie kontrola wewnętrzna w dzisiejszym rozumieniu. Analiza ryzyka obejmuje oszacowanie jego istotności, ocenę prawdopodobieństwa oraz sposób zarządzania ryzykiem³ ${ }^{3}$

System kontroli wewnętrznej jest procesem złożonym, który obejmuje wszystkie obszary działalności jednostki. W pierwszej części przedstawiono najważniejsze informacje dotyczące elementów, jakie powinien zawierać prawidłowo funkcjonujący proces. Ze względu na różną specyfikę, wielkość i zadania poszczególnych jednostek trudno jest wskazać jeden schemat, który będzie dobrze funkcjonował we wszystkich gminach, powiatach czy województwach. Prawidłowe funkcjonowanie systemu kontroli wewnętrznej będzie uzależnione więc od profesjonalizmu, chęci i dojrzałości zarówno pracowników administracji oraz najwyższego kierownictwa.

\section{EWOLUCJA KONTROLI WEWNĘTRZNEJ W SAMORZĄDZIE TERYTORIALNYM W POLSCE}

Zwiększajace się wymagania w stosunku do realizacji zadań i celów administracji publicznej oraz oczekiwania społeczne wskazały na potrzebę dokonania zmian w dotychczasowym systemie kontroli. Podjęto próbę wdrażania do polskiego porządku prawnego elementów doktryny New Public Management. Ma to na celu ukierunkowanie realizacji zadań publicznych przez lokalne samorządy na efektywność i skuteczność, a także na usprawnienie działania. Wymaga to przeorientowania mentalności pracowników administracji publicznej, zwłaszcza samorządowej, na zarządzanie menedżerskie. Jest to proces długotrwały i dość trudny z uwagi na dotychczasowe uwarunkowania.

${ }^{3}$ Committee of Sponsoring Organizations of the Treadway Commission, op. cit., s. 45. 
Jednym z elementów wprowadzenia anglosaskiego podejścia do zarządzania administracją samorządową jest próba wdrożenia kontroli zarządczej. W ustawie o finansach publicznych z 2009 r. poświęcono jej rozdział szósty. Zgodnie z art. 68 kontrola zarządcza w jednostkach sektora finansów publicznych to ogół działań podejmowanych dla zapewnienia realizacji celów i zadań w sposób zgodny z prawem, efektywny, oszczędny i terminowy. Natomiast cele kontroli zarządczej ustawodawca wyliczył w katalogu zamkniętym. Zalicza do nich ${ }^{4}$.

1) zgodność działalności z przepisami prawa oraz uregulowania wewnętrznymi;

2) skuteczność i efektywność działania;

3) wiarygodność sprawozdań;

4) ochronę zasobów;

5) przestrzeganie oraz promowanie etycznego postępowania;

6) efektywność i skuteczność przepływu informacji;

7) zarządzanie ryzykiem.

Wyszczególnione cele systemu kontroli zarządczej winny zwrócić uwagę czytelnika oraz stanowić przyczynek do postawienia tezy, że ten typ kontroli posiada znacznie szerszy zakres niż formy kontroli funkcjonujące we wcześniejszym porządku prawnym. Do 2010 r. pojęcie kontroli wewnętrznej nie było ukierunkowane na proces zarządzania jednostka sensu stricto. Tradycyjne pojęcie kontroli, które zostało wyżej omówione, było ujęciem w dość wąskim znaczeniu. Kontrola nie była ukierunkowana na kwestie związane z efektywnością i skutecznością działania.

Kontrola zarządcza odnosi się do procesu zarządzania całością organizacji z uwzględnieniem m.in. struktury organizacyjnej, obszaru finansowego przy jednoczesnym określeniu celów i mierników ich realizacji.

Początków kontroli wewnętrznej można upatrywać już w 1990 r., tj. w momencie uchwalenia ustawy o samorządzie terytorialnym. Organem, który jako pierwszy otrzymał kompetencje w ramach kontroli wewnętrznej, jest organ stanowiący, a dokładniej - komisja rewizyjna oraz inne powoływane komisje doraźne. Takie kompetencje komisja rewizyjna otrzymała w momencie zmiany ustawy, gdy zapisano, że w celu kontroli działalności zarządu i podporządkowanych mu jednostek rada gminy powołuje komisję rewizyjna. Obowiązek ten wynika $\mathrm{z}$ art. $18 \mathrm{a}$ ust. 1 ustawy o samorządzie gminnym ${ }^{5}$.

Zapisy dotyczące finansów samorządu gminnego początkowo były określone dość lakonicznie w ustawie ustrojowej. Dopiero w 1991 r. została podjęta przez Sejm ustawa regulująca bardziej szczegółowo finanse gmin, a mianowicie ustawa z 5 stycznia 1991 r. - Prawo budżetowe. Przyjęto w niej zapis, że wykonanie budżetu gminy podlega kontroli jej organowi stanowiącemu. Doprecyzowano również zadania zarządu w zakresie opracowania budżetu oraz jego wykonywania. Na mocy tej ustawy rada gminy rozpatrywała sprawozdanie z wykonania budżetu i podejmowała decyzję o udzieleniu absolutorium. Jednocześnie w odrębnym rozporządzeniu określono prawa i obowiązki głównych księgowych budżetów - skarbników. Na przestrzeni lat zapisy te

${ }^{4}$ Ustawa z 27 sierpnia 2009 r. o finansach publicznych, Dz. U. 2013, poz. 885 ze zm.

${ }^{5}$ Ustawa z 8 marca 1990 r. o samorządzie gminnym, Dz. U. 2013, poz. 594 ze zm. 
zostały przeniesione do ustawy o finansach publicznych. Sformułowano tam obowiązki głównych księgowych w zakresie kontroli wewnętrznej dokonywanych operacji finansowych. Kontrola wewnętrzna realizowana przez głównych księgowych nie uległa znaczącej zmianie.

Na mocy ustawy o finansach publicznych z $1998 \mathrm{r}$. wprowadzono pojęcie kontroli finansowej oraz audytu wewnętrznego w jednostkach sektora finansów publicznych. Kontrola finansowa utożsamiana była z kontrolą wewnętrzną i dotyczyła procesów związanych z gromadzeniem i rozdysponowaniem środków publicznych, a także gospodarowaniem mieniem ${ }^{6}$. Od 2010 r. została ona zastapiona kontrola zarządcza.

Pewnego rodzaju mankamentem uregulowań prawnych zawartych w ustawie jest lakoniczność oraz potraktowanie kontroli zarządczej w sposób ogólnikowy. Minister Finansów w ramach wydawanych komunikatów starał się wspomóc jst w prawidłowym wdrażaniu kontroli zarządczej. Pierwszy z wydanych komunikatów dotyczył standardów kontroli zarządczej. Został on oparty na modelu COSO, który zaprezentowano w ramach wcześniejszych rozważań. Standardy zostały przedstawione w pięciu grupach, które odpowiadają elementom kontroli zarządczej, czy też wewnętrznej. Sa nimi środowisko wewnętrzne, cele i zarządzanie ryzykiem, mechanizmy kontroli, informacja i komunikacja oraz monitorowanie i ocena ${ }^{7}$. W ramach Standardów podjęta została próba wyszczególnienia podstawowych aspektów, jakie powinny zostać objęte całym systemem. W kolejnych komunikatach zostały udzielone wskazówki dotyczące samooceny kontroli zarządczej oraz planowania i zarządzania ryzykiem.

Wiele miejsca kontroli zarządczej w swoich publikacjach, a także raportach poświęciła Najwyższa Izba Kontroli, która w 2010 r. negatywnie oceniła efekty wdrażania tego procesu w samorządach. W trakcie kontroli ustalono, że regulacje wewnętrzne były opracowywane bez powiązania z zarządzaniem ryzykiem, ponadto w dość wąskim stopniu nakierowane były na osiaganie celów, a także zapobieganie, wykrywanie czy też korygowanie nieprawidłowości. Przyczyn takiego stanu rzeczy Najwyższa Izba Kontroli upatruje m.in. w braku ujednoliconej metodyki wdrażania kontroli zarządczej. Podsumowując wyniki kontroli, zauważono, że koncepcja całego systemu kontroli zarządczej, podobnie jak audytu wewnętrznego, wymaga ponownego rozważenia, w aktualnym bowiem kształcie nie tylko nie przynosi zakładanych korzyści, ale nie daje również takich szans w przyszłości ${ }^{8}$. Wśród głównych słabości kontroli zarządczej w kontrolowanych samorządach wymieniano zwłaszcza brak dokonania przeglądów przed aktualizacjami procedur i brak procedur zarządzania ryzykiem.

${ }^{6}$ Ustawa z 16 listopada 1998 r. o finansach publicznych, Dz. U. 1998, Nr 155, poz. 1014 ze zm. (dalej jako: u.f.p.).

7 Komunikat nr 23 Ministra Finansów z 16 grudnia 2009 r. w sprawie standardów kontroli zarządczej dla sektora finansów publicznych, Dz. Urz. MF Nr 15, poz. 84.

${ }^{8}$ Najwyższa Izba Kontroli, Informacja o wynikach funkcjonowania kontroli zarzadczej w jednostkach samorzadu terytorialnego ze szczególnym uwzględnieniem audytu wewnętrznego, Gdańsk 2011, s. 7-11. 
Marzena Staniszewska i Mirosław Stasik podkreślaja, że aby kontrola zarządcza w samorządach była skutecznym narzędziem usprawniania państwa, musi nastapić faktyczne jej wdrożenie. System kontroli zarządczej nie może być ograniczany jedynie do tworzenia dokumentacji czy też sztucznych procedur. Funkcjonowanie kontroli zarządczej powinno mieć miejsce we wszystkich obszarach działalności jst, w tym w dwóch najistotniejszych, jakimi są zdolność do osiagania założonych celów oraz rzetelność przekazywanych informacji w oświadczeniach o stanie kontroli zarządczej ${ }^{9}$.

Na konieczność poprawy skuteczności i efektywności w polskiej administracji wskazuje również raport „Polska 2030. Wyzwania rozwojowe”. W wyzwaniu 9. odniesiono się do idei sprawnego państwa. Zwrócono uwagę, że administracja, podobnie jak inne polskie instytucje publiczne, jest pozbawiona dynamizmu, kreatywności, mechanizmów motywujących pracowników do zwiększania efektywności. Kluczowym dylematem w podnoszeniu efektywności jest kwestia wyboru pomiędzy autorskimi pomysłami na zmiany instytucjonalne bądź organizacyjne oraz wykorzystaniem doświadczeń z zakresu zarządzania wdrażanych szczególnie w sektorze prywatnym ${ }^{10}$.

W obecnej chwili uzupełnieniem systemu kontroli wewnętrznej w jst, a także w całym sektorze finansów publicznych jest audyt wewnętrzny. Został on wprowadzony w $1998 \mathrm{r}$. na mocy ustawy o finansach publicznych i był ukierunkowany na sferę finansowa. Ustawodawca określił, że audytem wewnętrznym jest ogół działań, przez które kierownik jednostki uzyskuje obiektywna oraz niezależną ocenę jej funkcjonowania w zakresie gospodarki finansowej. Ocena ta dotyczyła kryteriów legalności, gospodarności, celowości, rzetelności oraz przejrzystości i jawności ${ }^{11}$. Definicja audytu wewnętrznego ewoluowała więc tak, aby objąć całość działalności jednostki sektora finansów publicznych. W art. 272 wskazano, że jest to niezależna i obiektywna działalność mająca na celu wspieranie kierownika jednostki w realizacji zadań i celów. Ma to się odbywać w ramach systematycznej oceny kontroli zarządczej oraz przez czynności doradcze. Kryteria oceny kontroli zarządczej dotyczą: adekwatności, skuteczności i efektywności.

Zaprezentowana próba przedstawienia ewolucji systemu kontroli wewnętrznej, której ostatnim obecnie wdrożonym elementem jest kontrola zarządcza, skłania do refleksji, że jest to system bezpośrednio związany z zarządzaniem jednostką. W samorządach bardzo często dominuje stereotypowe podejście, że ten rodzaj kontroli odnosi się do porównania stanu faktycznego z oczekiwanym w pewnych odstępach czasu. Należy pamiętać o tym, że kontrola zarządcza powinna być sprawowana na bieżąco przez wszystkich pracowników. Jej następstwem powinno być dostarczenie najwyższemu kie-

\footnotetext{
${ }^{9}$ M. Staniszewska, M. Stasik, Jak poprawić funkcjonowanie kontroli zarzadczej $w$ administracji - rola audytu wewnętrznego, w: Kontrola Państwowa nr 1 (348), Najwyższa Izba Kontroli, Warszawa 2013, s. 84.

${ }_{10}$ Raport Polska 2030. Wyzwania rozwojowe, Kancelaria Prezesa Rady Ministrów, Warszawa 2009, s. 299.

11 U.f.p.
} 
rownictwu informacji niezbędnych do poczynienia działań mających na celu poprawę skuteczności i efektywności funkcjonowania jst.

Funkcję koordynatora działań w systemie kontroli zarządczej może pełnić również komórka kontrolingu. Jest ona wyposażona w uprawnienia do prowadzenia monitoringu, a także bierze udział w procesie identyfikacji celów zarówno na poziomie strategicznym, jak i operacyjnym. Można doszukiwać się wielu prawdopodobieństw pomiędzy kontrolingiem a kontrolą zarządczą. Najważniejszymi sa kompleksowość, orientacja na cele, mechanizmy samoregulacji ${ }^{12}$. Zastosowanie kontrolingu w samorządach może mieć istotne znaczenie przy realizacji budżetu zadaniowego, który opiera się na pomiarze dokonań. W literaturze funkcjonuje wiele definicji kontrolingu. Jest on jednak często wskazywany jako podsystem zarządzania obejmujacy kształtowanie i koordynację procesów planowania i kontroli. Pozyskuje on informacje przydatne w zarządzaniu jednostką przez pryzmat założonych celów ${ }^{13}$. System zarządzania oparty na sprawnie funkcjonującym systemie kontroli zarządczej, w ramach którego jest wykorzystywany kontroling, będzie wpływał na ocenę dokonań danej jednostki, a w konsekwencji na cały proces decyzyjny. Wykorzystanie kontrolingu pozwoli na uzyskanie bardziej wiarygodnych informacji niezbędnych do podnoszenia efektywności i skuteczności działania samorządu.

Reasumując, z perspektywy czasu doświadczenia związane z funkcjonowaniem kontroli wewnętrznej w samorządach można podzielić na cztery etapy. Ich wyznacznikiem są zmiany w systemie prawnym obejmującym m.in. sektor samorządowy. Etapy te zostały zaprezentowane w sposób możliwie najbardziej syntetyczny na schemacie 1 .

Pierwszy etap obejmuje moment utworzenia samorządu w wolnej Polsce. Wówczas kontrola wewnętrzna była dość uboga i odnosiła się zaledwie do działalności kontrolnej organu stanowiącego. W etapie drugim do systemu kontroli wewnętrznej dodano kontrolę finansową oraz audyt wewnętrzny, który ówcześnie odnoszono do aspektów finansowych jednostki. Obecnie można zaznaczyć, że kontrola wewnętrzna znajduje się na etapie trzecim. Podjęta została próba wdrożenia zmiany podejścia do kontroli wewnętrznej, która powinna być zorientowana na zarządzanie. Efektem tego było skorygowanie ustawowej definicji audytu wewnętrznego, wprowadzenie zapisów dotyczących kontroli zarządczej oraz zapoczątkowanie planowania strategicznego (wieloletnich prognoz finansowych). Na potrzebę doskonalenia i ponownego rozważenia koncepcji kontroli wewnętrznej w sektorze samorządowym wskazują instytucje kontroli zewnętrznej, ale również same samorządy. Niektóre gminy czy powiaty oddolnie wprowadzają kolejne elementy koncepcji New Public Management, tzn. budżet zadaniowy, a także kontroling. Pełne wdrożenie tej koncepcji będzie zatem stanowiło czwarty etap ewolucji kontroli wewnętrznej.

12 Z. Derdziuk, A. Niedzielski, Koordynacyjna funkcja kontrolingu, w: Kontrola Państwowa nr 6 (341), Najwyższa Izba Kontroli, Warszawa 2011, s. 11.

${ }^{13}$ E. Nowak, Controlling $w$ działalności przedsiębiorstwa, Warszawa 2011, s. 15. 


\section{Schemat 1}

Ewolucja kontroli wewnętrznej w samorządzie terytorialnym

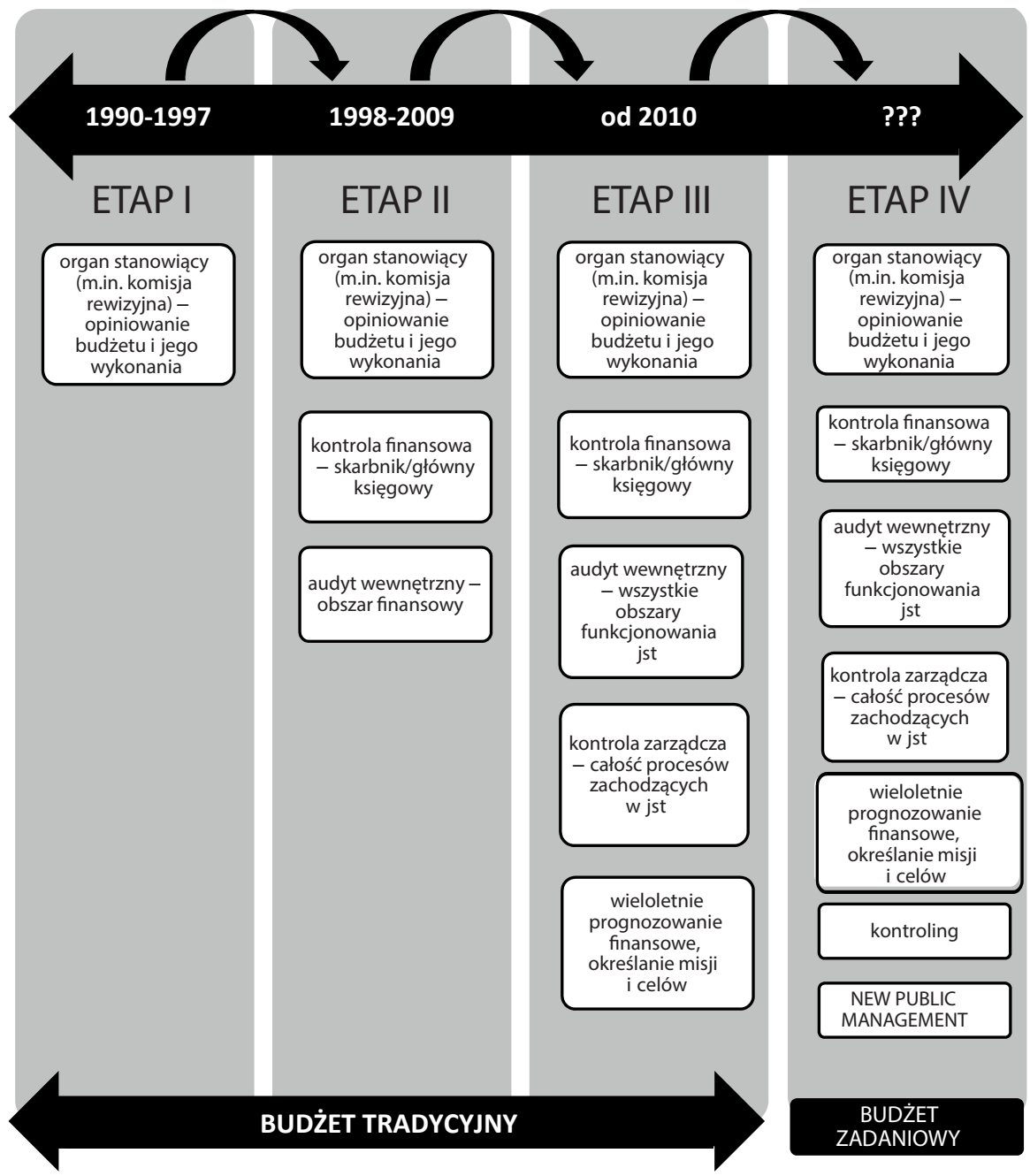

Źródło: opracowanie własne.

\section{BADANIA ANKIETOWE - KONTROLA ZARZĄDCZA}

Na potrzeby artykułu w grudniu 2014 r. skierowano do 200 jednostek samorządu terytorialnego ankietę dotycząca funkcjonowania kontroli zarządczej oraz audytu wewnętrznego. Otrzymano 149 wypełnionych ankiet, co stanowi $75 \%$ przesłanych ankiet do samorządów. Celem przeprowadzonego badania było uzyskanie informacji dotyczacych funkcjonowania kontroli zarządczej oraz audytu wewnętrznego w samorządach. Z otrzymanych ankiet wynika, 
że w znacznej większości odpowiedzi udzielały osoby lub komórki zajmujące się kontrolą zarządczą lub audytem wewnętrznym. Niżej zaprezentowano najważniejsze punkty i odpowiedzi ankietowanych wskazujące zarówno na mocne, jak i słabe strony funkcjonowania systemu.

Na podstawie badania ustalono, że do prowadzenia audytu wewnętrznego jest zobligowanych 128 samorządów, co stanowi 86\% uzyskanych odpowiedzi na pytanie, czy wielkość dochodów i przychodów lub wydatków i rozchodów przekracza kwotę 40000 tys. zł. Na podstawie przeprowadzonej ankiety ustalono, że - pomimo obowiązu wynikającego z ustawy - 5 samorządów nie przeprowadza audytu wewnętrznego. W przypadku 2 jst udzielono odpowiedzi, że trudno powiedzieć, czy audyt wewnętrzny jest prowadzony, co świadczy albo o faktycznym niewypełnieniu obowiązku ustawowego, albo o tym, że jednostki te zatrudniają audytora wewnętrznego, nie uzyskują jednak z tego faktu żadnej wartości dodanej. W kontekście audytu wewnętrznego zapytano również o wkład audytora w systemowe wspieranie kierownika jst w osiaganiu zaplanowanych rezultatów przez ocenę kontroli zarządczej i czynności doradcze. Uzyskane odpowiedzi zostały przedstawione na wykresie 1.

\section{Wykres 1}

Wkład audytu wewnętrznego w osiaganie zaplanowanych rezultatów

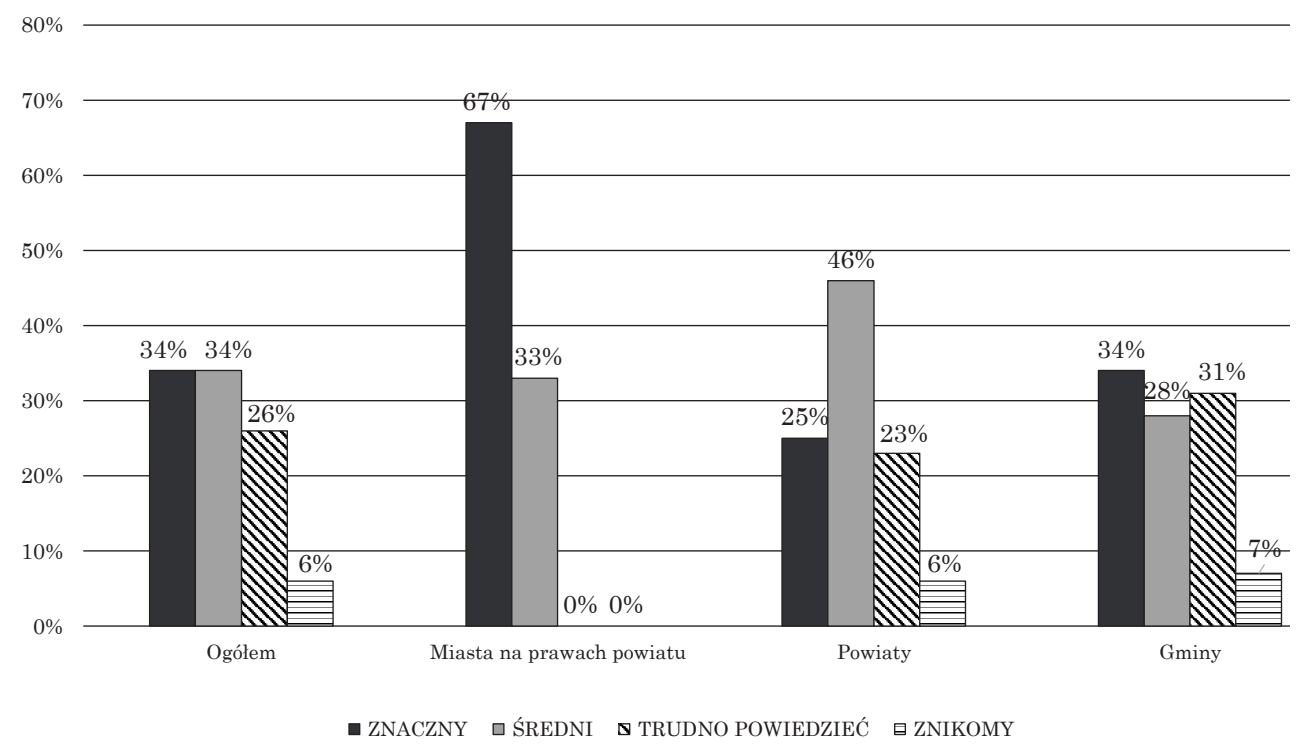

Źródło: opracowanie własne.

Z powyższego wykresu wynika, że wkład audytu wewnętrznego w osiaganie zaplanowanych celów jako znaczny ocenia 34\% wszystkich respondentów, którzy udzielili odpowiedzi w tej kwestii, podobnie jak w przypadku średniego wpływu audytu na funkcjonowanie samorządu. Dalsza interpretacja uzyskanych wyników została dokonana w podziale na poszczególne jst, w związku 
z czym wartości procentowe odnoszą się do wszystkich uzyskanych odpowiedzi w ramach danej grupy jst. Największą grupą samorządów doceniających audyt wewnętrzny są miasta na prawach powiatu, które w $67 \%$ oceniaja, że audyt wewnętrzny jest wartością dodaną. Niestety najgorzej wypadają powiaty, w których wkład audytu jako znaczny ocenia zaledwie jedna czwarta ankietowanych, a $46 \%$ powiatów uważa, że audyt wewnętrzny średnio wpływa na ich działalność. Podobnie rzecz ma się w gminach, w których niewiele wyższy jest wskaźnik przydatności audytu, który wynosi 34\% uzyskanych odpowiedzi z gmin. Biorąc pod uwagę przytoczone wyniki, można sformułować wniosek, że audyt wewnętrzny jest doceniany w dużych samorządach, jakimi bez wątpienia sa miasta na prawach powiatu. W gminach i powiatach ta przydatność audytu wewnętrznego jest dość zróżnicowana. Odpowiednio 7\% i 6\% ankietowanych, którzy udzielili odpowiedzi na to pytanie, uznało audyt wewnętrzny za znikomy, zwracając uwagę na koszty jego funkcjonowania. W tej części ankiety jst zwracały uwagę na przyczyny takiej oceny audytu wewnętrznego. Na niekorzyść przemawiaja kwestie związane z tym, że nie wszyscy członkowie najwyższego kierownictwa sa zainteresowani wynikami prac audytu wewnętrznego i zwracają uwagę, iż przy znacznej liczbie jednostek podległych komórka audytu wewnętrznego jest zbyt obciązona, co powoduje brak możliwości przeprowadzenia pełnej oceny stanu kontroli zarządczej we wszystkich jednostkach organizacyjnych. Zdaniem niektórych ankietowanych przeprowadzana przez audytora wewnętrznego ocena systemu kontroli zarządczej odbywa się post factum, co powoduje konieczność dokonywania korekt i zmian $\mathrm{w}$ już obowiąujących uregulowaniach. Według respondentów te nieprawidłowości uregulowań wewnętrznych można byłoby uwzględnić na etapie ich tworzenia, co byłoby uwarunkowane czynnym udziałem audytora w tym procesie. Jednakże w tym przypadku powstaja obawy dotyczące prawidłowości wykonywania kontroli zarządczej. Skutkiem czynności kontrolnych powinno być dokonanie korekty w uregulowaniach wewnętrznych. Natomiast jeżeli jest to dopiero następstwem działań audytu wewnętrznego, należy zauważyć, że przeprowadzana przez audytora zgodnie z ustawą o finansach publicznych ocena kontroli zarządczej może być negatywna w zakresie skuteczności, czy też efektywności. Jako zalety audytu wewnętrznego wiele jednostek wskazało, że pozwala on udoskonalić system i procesy związane z realizacją zadań w ramach kontroli zarządczej oraz usprawnić funkcjonowanie wszystkich jednostek organizacyjnych. Ponadto oceniając skuteczność kontroli zarządczej, respondenci wskazywali, że wyniki prac audytu są wsparciem dla najwyższego kierownictwa w zakresie obiektywnego spojrzenia na funkcjonowanie kontroli zarzadczej oraz zidentyfikowanych postaci ryzyka w ramach realizowanych zadań. Przydatność audytu wewnętrznego w funkcjonowaniu jst jest ocena subiektywna formułowana przez poszczególne samorządy. Na powyższą ocenę przekłada się więc nie tylko swoiste odczucie zasadności i roli audytu wewnętrznego, ale może w szczególności dojrzałość jednostek w sferze realizacji szeroko rozumianego procesu zarządzania.

W przeprowadzonym badaniu zapytano również o to, czy samorządy posiadają dokumenty określające misję oraz cele wraz z miernikami ich realizacji. Uzyskano informację, że 139 jst (93\% ogółu udzielonych odpowiedzi) po- 
siada stosowne dokumenty, w których zostały określone misja i cele. Jednak niektórzy ankietowani wskazali, że takim określeniem misji oraz celów jest obowiązujące prawodawstwo w zakresie ustroju samorządu. Budzi to więc wątpliwość, czy jst poprawnie rozumieją to zagadnienie, ponieważ zgodnie ze standardami kontroli wewnętrznej oraz zarządczej powinny mieć one konkretnie sformułowane misję oraz cele. Zaleca się więc stworzenie odrębnego dokumentu, który posłuży nie tylko środowisku wewnętrznemu samorządu, lecz także klientom zewnętrznym. Szczególnie może to być wartością dodana w komunikacji z mieszkańcami oraz partnerami biznesowymi. Pozytywny jest fakt, że w znacznej mierze jst posiadaja stosowne uregulowania w ramach długookresowych strategii rozwoju samorządu, w polityce jakości, wieloletnim planie inwestycyjnym, strategii rozwiązywania problemów społecznych oraz innych dokumentach. Wśród wszystkich 149 jednostek, które odpowiedziały na pytanie, czy zostały określone mierniki realizacji misji i celów, 73\% samorządów odpowiedziało twierdząco. Funkcjonujące mierniki odnoszą się m.in. do celów strategicznych i operacyjnych oraz stopnia realizacji zadań. Jednostki samorządu terytorialnego, w których wdrożony został budżet zadaniowy, zwracaja uwagę, że ułatwia on pomiar skuteczności i efektywności realizowanych zadań, a także komunikację $\mathrm{z}$ otoczeniem przez konkretne wskazanie celów samorządu. Sporządzane są również sprawozdania okresowe i roczne z realizacji założonych celów, jednak nieustająca trudnością jest prawidłowe formułowanie wskaźników przez pracowników. W tym celu zostały przeprowadzone okresowe szkolenia, dzięki którym uzyskano poprawę.

Wykres 2

Samorządy realizujące proces zarządzania ryzykiem

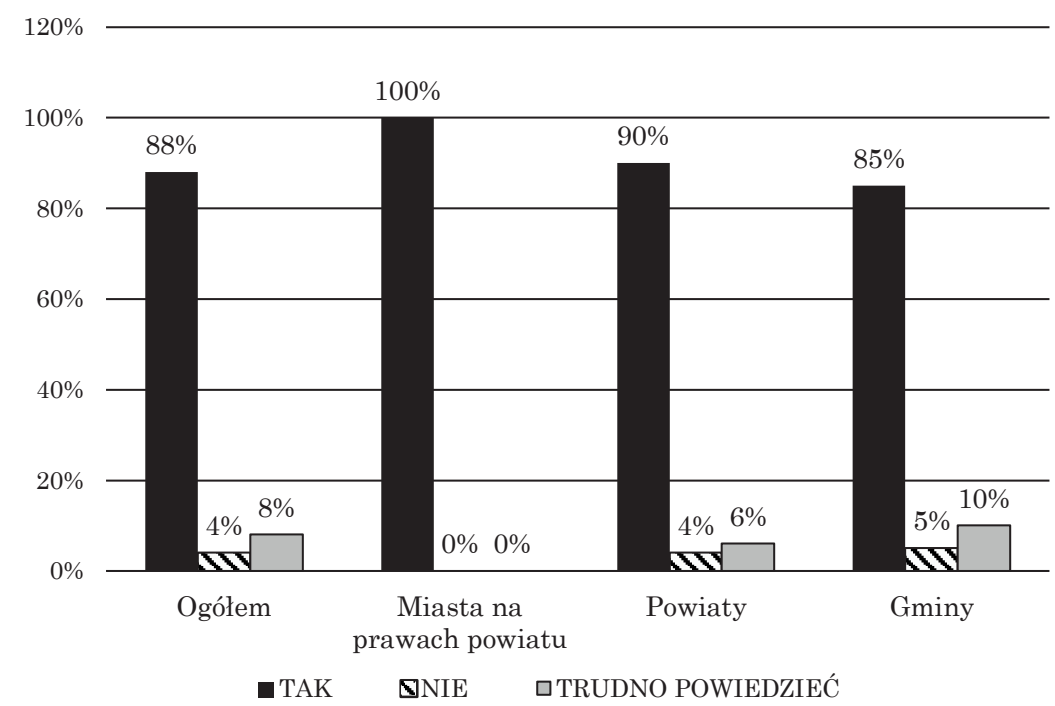

Źródło: opracowanie własne. 
Dla właściwego funkcjonowania systemu kontroli zarządczej kluczowe jest zarządzanie ryzykiem. Wydawałoby się, że ten element procesu powinien funkcjonować w blisko 100\% jednostek. Badanie wskazało, że w grupie jednostek, które udzieliły odpowiedzi na pytanie, czy realizują proces zarządzania ryzykiem, pozytywnie odpowiedziało zaledwie 88\% ankietowanych, tj. 131 jst. Również tyle samo samorządów zobowiązało jednostki podległe do identyfikacji ryzyka.

Z wykresu 2 wynika, że w grupie miast na prawach powiatu, które odpowiedziały na pytanie, proces zarządzania ryzykiem jest realizowany w 100\%, co może świadczyć o dobrym rozumieniu istoty kontroli zarządczej. Niestety jeżeli mowa o powiatach czy gminach, proces ten funkcjonuje odpowiednio w $90 \%$ oraz $85 \%$ samorzadów, które odniosły się do tego zagadnienia. Dodatkowo należy nadmienić, że $88 \%$ powiatów oraz $87 \%$ gmin zobligowało podległe jednostki do identyfikacji ryzyka. Uzupełnieniem podanych statystyk musi być sposób realizacji tego procesu. W większości jednostek są sporządzane ogólne bądź wydziałowe rejestry ryzyka. Wykorzystywane są również narzędzia informatyczne, do których dostęp z reguły mają wszyscy pracownicy, w celu bieżącego identyfikowania lub monitorowania już zidentyfikowanych postaci ryzyka. W ramach procesu zarządzania ryzykiem ustalane są również metoda przeciwdziałania dostrzeżonym postaciom ryzyka, poziomy akceptowalne dla nich, a także szczegółowe mechanizmy kontroli. W większości samorządów (116 na 149 uzyskanych ankiet) w proces zarządzania ryzykiem zaangażowani są wszyscy pracownicy, łącznie z najwyższym kierownictwem. Utworzone zostały również odrębne komórki organizacyjne, czy też zespoły do spraw kontroli zarządczej lub zarządzania ryzykiem. Z uwagi na fakt, że kontrola zarządcza odnosi się szczególnie do procesu zarządzania organizacja, najlepszym wyjściem jest zaangażowanie wszystkich pracowników, łącznie z najwyższym kierownictwem. Będzie to wartość dodana całego procesu i może istotnie wpłynąć na jakość zarządzania jst.

W przeprowadzonej ankiecie odniesiono się również do możliwości zastosowania kontrolingu w administracji samorządowej. Uzyskano informacje, że są samorządy wykorzystujące tę formę zarządzania, jednakże wśród 149 jednostek, które odpowiedziały na to pytanie, sa zaledwie 53, co stanowi tylko 36\% ogółu badanych. Wszyscy ankietowani, którzy odpowiedzieli twierdząco na pytanie o wykorzystania kontrolingu, zauważyli, że jego zastosowanie wpływa na efektywniejszą realizację zadań publicznych. W związku z tym jst, w których to funkcjonuje, doceniają ten fakt i wskazuja, że warto promować to rozwiązanie wśród pozostałych samorządów. Kontroling, zdaniem autora, może być uzupełnieniem skutecznego systemu kontroli zarządczej, a co za tym idzie - procesów zarządzania samorządem lokalnym.

\section{ZAKOŃCZENIE}

Każda organizacja, bez względu na to, czy jest to jst, czy też przedsiębiorstwo, potrzebuje skutecznego systemu kontroli wewnętrznej. Celem tego systemu jest wspieranie zarządzania w efektywnym osiaganiu zaplanowanych celów. 
Ewolucja kontroli wewnętrznej w sektorze samorządowym oraz dynamika zmian powinny być wsparte dodatkowo zmianą mentalności i świadomości zarówno pracowników, jak i najwyższego kierownictwa. Obecnie funkcjonujący system nie napawa optymizmem, jeżeli mowa o skuteczności i poprawie efektywności realizowanych zadań. Przeprowadzone badania ankietowe wskazuja, że jeżeli o przeprowadzanych audytach wewnętrznych w jst można wyrazić pozytywną opinię, to do funkcjonowania kontroli zarządczej należy mieć poważne zastrzeżenia. Pokazują też, że jednym z głównych problemów jest fakt, że tylko zdaniem $67 \%$ ankietowanych, którzy wzięli udział w badaniu, kontrola zarządcza pomaga kierownikowi jednostki w skutecznej i efektywnej realizacji zadań publicznych. Ponadto nie uzyskano zapewnienia od wszystkich samorządów, że w proces kontroli zarządczej zaangażowani są wszyscy pracownicy, łącznie z najwyższym kierownictwem. W badanej próbie 118 samorządów udzieliło takiego zapewnienia, co stanowi $79 \%$ ogółu udzielonych odpowiedzi. W pozostałych $21 \%$ w czynności w ramach kontroli zarządczej uczestniczy wyłącznie najwyższe kierownictwo lub powołana w tym celu wyspecjalizowana komórka. W związku z tym pojawiają się wątpliwości, czy kontrola zarządcza jest wykonywana na bieżąco czy też ex post. Wskazuje to na błędne rozumienie kontroli zarządczej, jej celów i płynących z niej informacji, które należałoby wykorzystać w kontekście wzmocnienia m.in. jakości realizowanych zadań publicznych.

W badaniach ankietowych samorządy zauważyły potrzebę wdrożenia budżetu zadaniowego, co pozwoliłoby na lepsze funkcjonowanie kontroli zarządczej. Zdaniem autora skutkowałoby to precyzyjnym określeniem misji i celów działania oraz mierników ich realizacji. Na słabość systemu kontroli zarządczej wskazują również niezadowalające wyniki raportów przedstawionych przez Najwyższą Izbę Kontroli.

W tym miejscu warto zwrócić uwagę, że część samorządów wspiera swoje systemy zarządcze przez aplikacje informatyczne, wdrażanie systemu CAF, samooceny i inne narzędzia. Zdaniem autora warto również zainteresować oraz rozpowszechniać inne systemy czy metody doskonalenia jakości, takie jak DMAIC (Define - Measure -Analyze - Improve - Control) lub DMADV (Define - Measure - Analyze - Design - Verify). Pierwsza jest nazywana cyklem doskonalenia procesu, druga zaś jest określana jako zarządzanie projektem nowego procesu. Warto również wykorzystać model doskonalenia oparty na tzw. cyklu Deminga (Planuj - Wykonaj - Sprawdź - Działaj). Nie jest to kwestia oderwania od rzeczywistości i braku możliwości zastosowania w administracji publicznej modeli zarządzania wykorzystywanych w przedsiębiorstwach. Przykładem na poszukiwanie nowych procesów doskonalenia jakości jest fakt wdrożenia przez niektóre samorządy normy ISO PN-EN 9001:2009.

Przykładów samorządów, w których świadomość potrzeby położenia nacisku na efektywność zarządzania jest niska, można podawać wiele, podobnie jak tych samorządów, które są zainteresowane poprawą jakości. Reasumując, w celu skutecznego funkcjonowania kontroli zarządczej w jst należałoby wdrożyć w samorządach w pełnym zakresie koncepcję New Public Management, a w sposób szczególny planowanie strategiczne oparte na celach 
i miernikach ich realizacji. Stanowiłoby to czwarty etap zaproponowanego modelu ewolucji. Nie ma konieczności dokonywania próby redefinicji pojęcia kontroli, lecz raczej sposobu jej realizacji i wykorzystania jej wyników w bieżącym zarządzaniu jst. Należy jednak pamiętać, że wszelkie procesy, procedury czy systemy wykorzystywane w samorządach powinny być na bieżąco monitorowane w celu dostosowywania do zmieniających się wymagań wobec tego sektora.

mgr Daniel Budzeń

Uniwersytet Ekonomiczny w Poznaniu

daniel.budzen@phd.ue.poznan.pl

\section{EVOLUTION OF THE INTERNAL CONTROL SYSTEM IN LOCAL SELF-GOVERNMENT OVER 25 YEARS OF SELF-GOVERNANCE IN POLAND}

Summary

The article is a summary of the internal control system in local self-government in Poland to mark the 25-years existence of local self-government. The main issues relating to internal control in public administration are presented. Internal control in local self-government units based on full implementation of the concept of New Public Management is presented, followed by the discussion of the results of its implementation and the role of management control and internal audit in local self-government. The paper is also an attempt to draw attention to the need for a change in the mentality and awareness of society, both of public administration as well of residents, in order to improve the quality of the tasks carried out by local self-government. 
